\title{
Genotoxic and Mutagenic Effects of the Antifouling Biocide Chlorothalonil on the Estuarine Fish Micropogonias Furnieri, Desmarest, 1823
}

\section{Muryllo Santos Castro}

Universidade Federal do Maranhão: Universidade Federal do Maranhao

\section{Larissa Cristine Carvalho Penha}

Universidade Federal do Maranhão: Universidade Federal do Maranhao

\section{Thamires Alexsandra Torres}

Universidade Federal do Maranhão: Universidade Federal do Maranhao

\section{Marianna Basso Jorge}

Universidade Federal do Maranhão: Universidade Federal do Maranhao

\section{Luis Fernando Carvalho-Costa}

Universidade Federal do Maranhão: Universidade Federal do Maranhao

\section{Gilberto Fillmann}

Universidade Federal do Rio Grande

Ricardo Luvizotto-Santos ( $\square$ luvizottosantos@hotmail.com )

Universidade Federal do Maranhão: Universidade Federal do Maranhao 3828-8930

\section{Research Article}

Keywords: Antifouling paints, booster biocides, comet assay, nuclear abnormalities, micronucleus test, whitemouth croaker

Posted Date: March 2nd, 2021

DOI: https://doi.org/10.21203/rs.3.rs-249058/v1

License: (c) (i) This work is licensed under a Creative Commons Attribution 4.0 International License. Read Full License 


\section{Abstract}

Chlorothalonil is a widely used fungicide in agriculture, and as biocide in antifouling paints. Although it causes toxic effects on non-target organisms and can bioaccumulate in fish tissues, little is known about its sublethal effects. Thus, we evaluated the genotoxic and mutagenic effects of chlorothalonil in Micropogonias furnieri, an estuarine and commercially important fish with potential as a test organism for ecotoxicology assays. We showed that chlorothalonil exerts genotoxic (DNA damage) and mutagenic (micronuclei and nuclear abnormalities) in a dose-dependent manner $\left(0.35\right.$ and $\left.3.5 \mathrm{\mu g} \mathrm{g}^{-1}\right)$. As the genomic instability may lead to carcinogenesis, our data can assist decision-makers with evidence for banning this compound since any benefit to portuary activities and maritime navigation is outweighed by the cost to aquatic ecosystems and to human health.

\section{Introduction}

Chlorothalonil (2,4,6,6-tetrachloroisophthalonitrile) (CHLT) is a broad-spectrum non-systemic fungicide from the isophthalonitrile group widely used in agriculture (Wu et al. 2012). Moreover, it has been used as biocide in the manufacture of antifouling paints, increasing its presence in the aquatic environment (Gallo and Tosti 2015). As a consequence, this biocide is found in high concentrations in port regions such as the Mediterranean, United Kingdom, Greece, and Korea (Voulvoulis et al. 2000; Sakkas et al. 2002; Lee et al. 2011).

The antifouling boosters prevent the establishment and growth of aquatic organisms - bacteria, microalgae, and invertebrates - on submerged or semi-submerged surfaces (Yebra et al. 2004). Its usage is increasing since fouling organisms cause damage to the vessel's structure, loss of speed due to hull irregularities, increase in fuel consumption, and longer mooring period (Brito et al. 2014). However, these biocides can affect non-target species from marine and estuarine environments in addition to fouling organisms (Sakkas et al. 2002), such as fish (Caux et al. 2015).

CHLT has a moderated Log $\mathrm{K}_{\text {ow }}$ of 2.64 , low solubility in water $\left(0.6 \mathrm{mg} \mathrm{L}^{-1}\right)$ and is extremely susceptible to photodegradation due to a half-life up to four weeks in seawater (Davies 1987) and eight to nine days in estuarine water (Caux et al. 2015). The high toxicity of chlorothalonil is related to the multiple reactive electrophilic centers in the molecule which depletes the levels of glutathione (GSH), a major player in organisms defenses against xenobiotics (Long and Siegel 1975).

Due to its toxic potential, this biocide has been banned from the United Kingdom (Thomas and Brooks 2010), and recently from the European Union and Switzerland due to its carcinogenic potential (Kiefer et al. 2020). In Brazil, ANVISA (Brazilian Health Regulatory Agency) created a model for reevaluating pesticides based on risk criteria for human health, and ranked Chlorothalonil as a potential carcinogen (ANVISA, 2019). However, little is known about the genotoxic and mutagenic potential (i.e., sublethal or chronic effects) of CHLT to non-target aquatic organisms. Such studies can be used for Health 
Surveillance given that their predictive character as indicator of carcinogenic effects might be useful to define which substances and concentrations are allowed to be used for each purpose.

Biomarkers are valuable tools to study the effects of toxicants on organisms. The comet assay, micronucleus test, and nuclear abnormalities are the most used ones to assess the potential risk of chemicals to cause DNA damage and mutation. Fishes are among the most widely used organisms for detecting harmful effects of xenobiotics, even when exposed to low concentrations, due to their high sensitivity and capacity to bioaccumulate (Yancheva et al., 2015). Micropogonias furnieri (whitemouth croaker) is a native estuarine fish that has been used for biomonitoring, since it is abundant and commercially relevant along the Brazilian coast (Marcovecchio, 2004; Amado et al., 2006). Thus, we used M. furnieri as ecotoxicological test organism to assess the potential of genotoxic and/or mutagenic effects associated with exposure to sublethal concentrations of CHLT.

\section{Methodology}

\section{Test organism}

M. furnieri was collected in estuarine streams in the town of Raposa (Maranhão State, Northeast Brazil: $2^{\circ} 25^{\prime} 19.8^{\prime \prime S} 44^{\circ} 05^{\prime} 29.4^{\prime \prime} \mathrm{W}$ ), using a $30 \mathrm{~mm}$ mesh cast-net (SisBio-IBAMA License N. 55187-1). Juvenile specimens (total length < $250 \mathrm{~mm}$; Juras, 1984) were pre-selected in situ $(\mathrm{n}=80)$ and transported in a recipient with local water and constant aeration to the laboratory. At the laboratory, they were measured, weighed (length $<250 \mathrm{~mm}$; weight $=18.3 \mathrm{~g} \pm 4 \mathrm{~g}$ ), and forwarded to a pre-treatment following Blaylock et al (2005). Briefly, they first received a freshwater bath for 3-5 minutes and then were acclimatized for 11 days $\left(25^{\circ} \mathrm{C} \pm 1{ }^{\circ} \mathrm{C}, 12 \mathrm{C} / 12 \mathrm{D}\right.$ photoperiod, salinity $=20 \mathrm{~g} / \mathrm{kg}$ and constant aeration $)$ in $310 \mathrm{~L} \mathrm{PVC}$ tanks with canisters filters at a density of $1 \mathrm{~g} \mathrm{~L}^{-1}$. Fishes were fed ad libitum with shrimp twice a day.

\section{Exposure treatments}

After acclimatized, fishes were randomly distributed into four experimental groups (20 individuals per group): (1) a negative control that received an intraperitoneal dosage of the "vehicle" (physiological solution for fish and dimethyl sulfoxide-DMSO in the proportion 99:1 (v:v)); (2) a positive control that received the "vehicle" and cyclophosphamide $\left(50 \mu \mathrm{g} \mathrm{g}^{-1}\right)$, a well known genotoxic and mutagenic agent (Anderson et al. 1995); (3) received the "vehicle" and CHLT at $0.35 \mu \mathrm{g} \mathrm{g}^{-1}$; and (4) received the "vehicle" and $\mathrm{CHLT}$ at $3.5 \mu \mathrm{g} \mathrm{g}^{-1}$.

Intraperitoneal injections were used to avoid the generation of toxic biocide residues and to achieve biocide accumulation in tissues. According to Kinkel et al. (2010), intraperitoneal injections are more effective for delivering a defined quantity of a chemical to each fish based on weight, particularly in experiments related to metabolic studies. The CHLT lowest dose was based on the bioconcentration factor of 18 of the marine fish Galaxias sauratus after 14 days of exposure to $20 \mathrm{\mu g} \mathrm{L}^{-1}$ of CHLT 
dissolved in water (Davies 1988). The lowest concentration was considered as the non-lethal one that accumulates in wet tissues; the highest one - one order of magnitude higher - was considered as the sub-lethal. The specimens were weighed and received an intraperitoneal dosage of $1 \mu \mathrm{L} \mathrm{g}^{-1}$ according to each treatment. After injections, fishes were kept for $96 \mathrm{~h}$ (without feeding) in the same conditions of acclimatization and then anesthetized with eugenol $\left(100 \mathrm{mg} \mathrm{L}^{-1}\right)$. A sample of peripheral blood was taken from the brachial artery (Research ethics committee authorization: CEUA-UFMA N.23115.008075/201612) to assess the potential of genotoxic and/or mutagenic effects.

\section{Genotoxic and mutagenic assays}

The comet assay was performed according to Cestari et al. (2004) modifications on Singh et al. (1988) and Tice et al. (2000) protocols. After the blood sample $(10 \mu \mathrm{L})$ be diluted in $1 \mathrm{~mL}$ of fetal bovine serum (GoldLab, Brazil), $10 \mu \mathrm{L}$ of this solution were mixed with $120 \mu \mathrm{L}$ of low melting fusion point agarose $(0.5 \%)$ (Agargen, Brazil). This mixture was poured on glass slides covered with regular agarose $(1.5 \%)$ (Agargen, Brazil). Slides were covered with coverslips and remained at $4^{\circ} \mathrm{C}$ for 10 to 20 minutes. After removing the coverslip, slides were dipped in ice-cold lysis solution $\left(2.5 \mathrm{M} \mathrm{NaCl}, 100 \mathrm{mM} \mathrm{Na}{ }_{2}\right.$ EDTA, 10 $\mathrm{mM}$ Tris $\mathrm{pH} 10,10 \% \mathrm{DMSO}$, and $1 \%$ Triton $\mathrm{X}-100$ ) and left for $1 \mathrm{~h}$ at $4^{\circ} \mathrm{C}$. Slides were disposed in a horizontal electrophoresis vat placed in an ice-filled plastic box to keep the material refrigerated. The gel electrophoresis ( $25 \mathrm{~V}$ and $300 \mathrm{~mA}$ ) took place for 25 minutes in alkaline buffer (10 M NaOH, $0.2 \mathrm{M} \mathrm{EDTA})$ and distilled water $(\mathrm{pH}>13)$ and transferred to a neutralization solution $(0.4 \mathrm{M} \mathrm{Tris} / \mathrm{HCl}, \mathrm{pH} 7.5)$ for 15 minutes, and allowed to dry at room temperature. Slides were fixed with absolute ethanol for 5 minutes, stained with ethidium bromide $\left(30 \mu \mathrm{g} \mathrm{ml}^{-1}\right)$, and analyzed under a fluorescence microscope (BX51/BX52Olympus; filter 516-560nm; 40x objective).

The tail sizes of the erythrocyte nucleoids (100 nucleoids/slide/individual) were classified according to the damage in the DNA (= nucleoid tail size) into five classes: 0 - no damage $(<5 \%) ; 1$ - low level of damage (5-20\%); 2 - medium level of damage (21-40\%); 3 - high levels of damage (41-94\%); and 4 - total damage (> 95\%) (Speit and Hartmann 1995). The damage score was obtained by multiplying the number of nucleoids in each class by the value of the respective class, and divided by the number of nuclei (= cells) analyzed, according to the formula by Speit and Hartmann (1995):

Score $=[(0 \times n 0)+(1 \times n 1)+(2 \times n 2)+(3 \times n 3)+(4 \times n 4)] /$ total number of cells

The micronucleus test followed the technique described by Hooftman and Raat (1982). A blood sample was smeared on a slide, fixed using methanol for 10 minutes, and left drying at room temperature. Slides were stained with the Panoptic hematological kit (Laborclin, Brazil) for 20 minutes, washed in running water, and dried at room temperature. The frequency of micronuclei in erythrocytes was determined by analyzing 1,000 cells per sample, considering only red blood cells with intact nuclear and cytoplasmic membranes. Micronuclei were classified according to Hooftman and Raat (1982) and the nuclear 
abnormalities (nuclear bud, apoptotic fragments, bilobed cells, and binucleated cells) according to Barsiene et al. (2006)

\section{Data analysis}

The normal distribution and homogeneity of the data sets were evaluated by the Shapiro Wilk and Levene tests, respectively. Since the data sets did not fit a normal distribution, we used the Kruskal-Wallis test, followed by the Dunnet test $(p<0.05)$, to evaluate the statistical significance of the differences for each biomarker among treatments.

\section{Results}

M. furnieri showed to be resistant to manipulation (capture and transportation) and acclimation to laboratory conditions as no mortality or incidence of disease during these periods were observed. The fish was also sensitive to CHLT and cyclophosphamide (positive control).

Both concentrations of CHLT caused DNA damage $(\mathrm{p}<0.05)$ in $M$. furnieri with a 2.8-fold increase in the damage scores (genotoxic effects) compared to the negative control and at a similar magnitude as the positive control (Fig. 1A). The micronucleus frequency (Fig. 1B) also revealed mutagenic effects $(p<0.05)$ for both dosages of CHLT ( 0.35 and $3.5 \mu \mathrm{g} \mathrm{g}^{-1}$ ), with an increase of 3.1 and 7.0-fold, respectively, compared to the negative control $(p<0.05)$. The higher dosage caused micronuclei similarly as the positive control. The effect was dose-dependent only for micronucleus $(p<0.05)$.

We also observed statistically significant effects in the formation of nuclear buds compared to the negative control, with a 2.8-fold increase for the positive control in the lowest concentration $\left(0.35 \mu \mathrm{g} \mathrm{g}^{-1}\right)$ and a 1.9-fold increase in the highest one $\left(3.5 \mu \mathrm{g} \mathrm{g}^{-1}\right)$, but no statistical differences between dosages and the positive control (Fig. 2A). The positive control and CHLT (both dosages) also induced the formation of apoptotic fragments, causing an increase of 14.5, 6.0 and 13.8-fold higher than the negative control (Fig. 2B). The number of bilobed cells was also significantly higher for the positive control and CHLT exposures than the negative control, with an increase of 2.9, 3.0 and 6.9-fold, respectively (Fig. 2C). On the other hand, despite increased frequency of binucleated cells, no statistical $(p>0.05)$ effects were observed for both the positive control and CHLT treatments (Fig. 2D). For nuclear abnormalities, only the frequencies of apoptotic fragments and bilobed cells were dose-dependent $(p<0.05)$.

\section{Discussion}

M. furnieri is suitable as a test organism species for ecotoxicological assays. Although it has been used as a biomonitor for aquatic pollution (e.g., Kehrig et al. 2002; Marcovecchio 2004; Amado et al. 2006; Tortelli et al. 2006; Seriani et al. 2011), there are no cases in the literature using the species for ecotoxicological assays. The species follows the criteria as an appropriate test organism species, such as: highly available and abundance, trophic level, environmental significance, wide distribution, 
commercial importance, easy manipulation, and sensibility to chemical exposure (Segner and Baumann 2015). Plus, as a native and commercial species, the results can be translated to their wild counterparts.

The biomarkers show that CHLT cause DNA damage (comet assay) and mutation (micronucleus test and nuclear abnormalities, except for binucleated cells) in a dose-dependent manner, sometimes similar to the positive control. These effects may be associated to an increase in oxidative stress - increasing the production of reactive oxygen species (ROS) - and/or to a decrease in the antioxidant defenses, such as glutathione (Pompella et al. 2003; Gagné 2014; Bacchetta et al. 2017; García-Medina et al. 2017). A mutagenic effect of CHLT was also shown for the guppy Poecilia vivipara (Lopes et al. 2019) when exposed to 1 and $10 \mu \mathrm{g} \mathrm{L}^{-1}$ of CHTL concentration. Micronuclei, as well as all other anomalies, have a similar origin, such as failure in cell repair, DNA replication damaged, improperly condensed chromatin, chromosome fragments without telomeres, and nucleus centromeres (Lindberg et al. 2007).

The mechanism of chlorothalonil action resembles reactions involving both low and high molecularweight thiols, and its toxicity resides in inhibiting thiol-dependent enzymes (Tillman et al. 1973). Arvanites and Boerth (2001), working with fungi confirmed that CHTL toxicity was associated with the rapid conjugation of cellular thiols derivatives with $\mathrm{CHTL}$, specifically with thiol-rich enzymes, such as GAPDH (glyceraldehyde-3-phosphate dehydrogenase) and GSH, depleting cellular GSH reserves. It is known that GSH is an important protein in the cellular defense, being able to act also against toxic xenobiotics such as drugs, pollutants, and carcinogens compounds. It is important to note that exposure to CHLT also causes an increase in enzyme gluthatione $s$-transferase (GST) activity in fish (Davies 1985; Lopes et al. 2019) reducing GSH availability, and decreasing its protective role in the cell's antioxidant defense, especially, in ROS neutralization.

Recent studies with different kinds of biomarkers have been used to identify CHLT potential for toxicity on different kinds of organisms (Table 1), revealing three groups of responses: genetics, biochemicals, and physiological. Genetic responses include: (1) induced transcription of genes involved in oxidative stress, lipid peroxidation, reactive oxygen species, and DNA damage in fish (Garayzar et al. 2016); (2) decreased expression of genes related to immunity, reproduction, and xenobiotic clearance in fish (Garayzar et al. 2016); (3) increased micronucleus in fish (Lopes et al. 2019); and (4) teratogenic effects in Ascidians (Gallo and Tosti 2015). 
Table 1

Effects of chlorothalonil in non-target organisms.

\begin{tabular}{|c|c|c|}
\hline Organism & Effects & Reference \\
\hline Zebrafish & Increase: GST, CAT, SOD, LPO, and ROS. & $\begin{array}{l}\text { Da Silva Barreto } \\
\text { et al., (2020) }\end{array}$ \\
\hline \multirow[t]{2}{*}{ Mussel } & Increase: SOD, and GST. & \multirow{2}{*}{$\begin{array}{l}\text { Guerreiro et al., } \\
(2020)\end{array}$} \\
\hline & Decrease: GCL, LPO, and protein carbonylation. & \\
\hline \multirow[t]{2}{*}{ Guppy } & $\begin{array}{l}\text { Increase: GCL (glutamate-cysteine-ligase), GSH, LPO, ROS, and } \\
\text { micronucleus. }\end{array}$ & \multirow[t]{2}{*}{$\begin{array}{l}\text { Lopes et al., } \\
(2019)\end{array}$} \\
\hline & Decrease: GST, and sperm quality. & \\
\hline \multirow[t]{2}{*}{ Mussel } & Increase: cellular adhesion, phagocytic activity. & \multirow{2}{*}{$\begin{array}{l}\text { Guerreiro et al., } \\
\text { (2017) }\end{array}$} \\
\hline & Decrease: hemocyte viability, and air survival capacity. & \\
\hline \multirow[t]{2}{*}{ Polychaeta } & Increase: GST, and LPO. & \multirow{2}{*}{$\begin{array}{l}\text { Da Silva Barreto } \\
\text { et al., (2017) }\end{array}$} \\
\hline & Decrease: ACAP, GSH, and AChE. & \\
\hline \multirow[t]{2}{*}{ Zebrafish } & $\begin{array}{l}\text { Increase: transcription of genes related to division and DNA } \\
\text { damage. }\end{array}$ & \multirow[t]{2}{*}{$\begin{array}{l}\text { Garayzar et al., } \\
(2016)\end{array}$} \\
\hline & $\begin{array}{l}\text { Decrease: expression of genes related to immunity, reproduction, } \\
\text { and xenobiotic clearance. }\end{array}$ & \\
\hline Zebrafish & $\begin{array}{l}\text { Exerts: estrogen receptor a (ERa) agonist activity, thyroid receptor } \\
\text { b (TRb) agonistic, and antagonistic activities. }\end{array}$ & $\begin{array}{l}\text { Zhang et al., } \\
\text { (2016) }\end{array}$ \\
\hline \multirow[t]{3}{*}{ Ascidians } & Deleterious effects on gametes and fertilization; & \multirow{3}{*}{$\begin{array}{l}\text { Gallo and Tosti } \\
(2015)\end{array}$} \\
\hline & $\begin{array}{l}\text { Interference in embryonic development as induction in larval } \\
\text { malformation; }\end{array}$ & \\
\hline & Teratogenic effects. & \\
\hline Amphibians & $\begin{array}{l}\text { Increase: numbers of liver granulocytes and melanomacrophages, } \\
\text { corticosterone, immune cell levels, and liver damage. }\end{array}$ & $\begin{array}{l}\text { Mcmahon et al., } \\
(2011)\end{array}$ \\
\hline $\begin{array}{l}\text { Rainbow } \\
\text { trout }\end{array}$ & $\begin{array}{l}\text { Increase: phagocytic leukocytes, respiratory burst, and phagocytic } \\
\text { cells. }\end{array}$ & $\begin{array}{l}\text { Shelley et al., } \\
\text { (2009) }\end{array}$ \\
\hline \multirow[t]{2}{*}{ Rat } & $\begin{array}{l}\text { Increase: PLOOH (phospholipid hydroperoxides), } \mathrm{PCOOH} \\
\text { (phosphatidylcholine hydroperoxide), PEOOH } \\
\text { (phosphatidylethanolamine hydroperoxide). }\end{array}$ & \multirow[t]{2}{*}{$\begin{array}{l}\text { Suzuki et al., } \\
(2004)\end{array}$} \\
\hline & Decrease: GSH. & \\
\hline
\end{tabular}

CAT: Catalase, SOD: Superoxide dismutase, LPO: lipid peroxidation, GCL: glutamate cysteine ligase, ACAP: Antioxidant capacity against peroxyl radicals, Era: estrogen receptor $a$, TRb: thyroid receptor $b$, PLOOH: phospholipid hydroperoxides, $\mathrm{PCOOH}$ : phosphatidylcholine hydroperoxide, $\mathrm{PEOOH}$ : phosphatidylethanolamine hydroperoxide. 


\begin{tabular}{|lll|}
\hline Organism & Effects & Reference \\
\hline Oyster & Decrease: phagocytic capacity, ROS; and pyridine nucleotide. & $\begin{array}{l}\text { Baier-Anderson } \\
\text { and Anderson } \\
\text { (2000a) }\end{array}$ \\
\hline $\begin{array}{l}\text { Striped } \\
\text { bass }\end{array}$ & $\begin{array}{l}\text { Decrease: cell viability, GSH synthesis. Suppress: baseline and } \\
\text { stimulated } \mathrm{O}_{2} \text { production by macrophage NADPH oxidase. }\end{array}$ & $\begin{array}{l}\text { Baier-Anderson } \\
\text { and Anderson } \\
\text { (2000b) }\end{array}$ \\
\hline $\begin{array}{l}\text { CAT: Catalase, SOD: Superoxide dismutase, LPO: lipid peroxidation, GCL: glutamate cysteine ligase, } \\
\begin{array}{l}\text { ACAP: Antioxidant capacity against peroxyl radicals, Era: estrogen receptor a, TRb: thyroid receptor b, } \\
\text { PLOOH: phospholipid hydroperoxides, PCOOH: phosphatidylcholine hydroperoxide, PEOOH: } \\
\text { phosphatidylethanolamine hydroperoxide. }\end{array}\end{array}$ \\
\hline
\end{tabular}

Biochemical responses include alterations in biomarkers of oxidative stress and increase in lipoperoxidation in estuarine polychaete (Laeonereis acuta) (Da Silva Barreto et al. 2017), mussels (Perna perna) (Guerreiro et al. 2020), fish (Poecilia vivipara) (Lopes et al. 2019; Da Silva Barreto et al. 2020) and in rat hepatocytes (Suzuki et al. 2004). Physiological effects include: (1) decreasing total motility, progressive motility and mitochondrial functionality of sperm quality in fish (Lopes et al. 2019); (2) alterations of the immune system in fish (Baier-anderson and Anderson 2000b; Shelley et al. 2009), mollusks (Baier-anderson and Anderson 2000a; Guerreiro et al. 2017), and amphibians (Mcmahon et al. 2011); (3) disruptive effects in fish hormones (Zhang et al. 2016); and (4) disruptive effects in reproduction of Ascidians (Gallo and Tosti 2015).

In addition to be potentially genotoxic and mutagenic, CHLT is also a potential carcinogen. The United States Environmental Protection Agency (US EPA) ranks CHLT as a suspected carcinogen to humans based on studies with mice (US EPA, 1999). In Brazil, the National Health Surveillance Agency created a model for reevaluating pesticides based on risk criteria for human health. In this assessment, Chlorothalonil is ranked as a potential carcinogen for humans (ANVISA, 2019). Other studies have shown clearly the carcinogenic effects of chlorothalonil in fish (Lopes et al., 2019, Garayzar et al., 2016 and Gallo and Tosti, 2015). Our results also suggest that CHLT may be involved with carcinogenesis because it causes genomic instability and mutation, which might overwhelm the DNA repair system.

Banning CHLT as occurred in the United Kingdon, European Union and Switzerland (Kiefer et al 2020) should be in sight of the Brazilian health authorities. Any benefits to portuary activities and maritime navigation provided by CHLT-based antifouling paints is outweighed by the risks of its biomagnification through the food chain - eventually reaching humans - the carcinogenic potential and the damage to aquatic ecosystems.

\section{Conclusion}

The estuarine fish $M$. furnieri has the potential for use as a test organism in ecotoxicological assays. We also show that chlorothalonil causes DNA damage and mutation, probably, by depleting GSH availability, a major player in the cell's antioxidant defense. As the genomic instability and mutation may lead to carcinogenesis, our data can assist decision-makers with evidence for banning this compound from 
antifouling paints since any benefit to portuary activities and maritime navigation is outweighed by the cost to aquatic ecosystems and human health.

\section{Declarations}

\section{Ethics approval}

Research ethics committee authorization: CEUA-UFMA N.23115.008075/2016-12 (attached).

\section{Consent to participate.}

Not applicable in this section.

\section{Consent for publication.}

Not applicable in this section.

\section{Availability of data and materials.}

Not applicable in this section.

\section{Competing interests}

The authors declare that they have no competing interests

\section{Funding}

Financial support was provided by Coordenação de Aperfeiçoamento de Pessoal de Nível Superior (CAPES - CIMAR II Project No 1988/201). G. Fillmann was sponsored by Conselho Nacional de Desenvolvimento Científico e Tecnológico (CNPq - PQ 312341/2013-0).

\section{Authors' contributions}

MSC and RLS conceived and designed the study. MSC, LCCP, TAT, LFCC, MBJ conducted the literature search. MSC, LCCP, TAT was involved in the analysis and interpretation of data. MSC, LCCP, TAT, LFCC, MBJ and RLS drafted the manuscript. The study was supervised by LFCC, MBJ, GF and RLS. All authors read and approved the manuscript. 


\section{Acknowledgments}

The authors would like to thank Paulo Victor Miranda Figueiredo for the essential help in the fish collection and its maintenance in laboratory.

\section{References}

1. Amado LL, Da Rosa CE, Leite AM, et al (2006) Biomarkers in croakers Micropogonias furnieri (Teleostei: Sciaenidae) from polluted and non-polluted areas from the Patos Lagoon estuary (Southern Brazil): Evidences of genotoxic and immunological effects. Mar Pollut Bull 52:199-206. doi: 10.1016/j.marpolbul.2005.11.006

2. Anderson D, Bishop JB, Garner RC, et al (1995) Cyclophosphamide: Review of its mutagenicity for an assessment of potential germ cell risks *. Mutat Res 330:115-181. doi: 10.1016/00275107(95)00039-I

3. Agência Nacional de Vigilância Sanitária - ANVISA (2019). Nova metodologia define reavaliação de agrotóxicos. Disponível em https://www.gov.br/anvisa/pt-br/assuntos/noticias-anvisa/2019/novametodologia-define-reavaliacao-de-agrotoxicos, acessado em outubro de 2020.

4. Arvanites AC, Boerth DW (2001) Modeling of the mechanism of nucleophilic aromatic substitution of fungicide chlorothalonil by glutathione. J Mol Model 7:245-256. doi: 10.1007/s008940100032

5. Bacchetta C, Ale A, Simoniello MF, et al (2017) Genotoxicity and oxidative stress in fish after a shortterm exposure to silver nanoparticles. Ecol Indic 76:230-239. doi: 10.1016/j.ecolind.2017.01.018

6. Baier-Anderson C, Anderson RS (2000a) The Effects of Chlorothalonil on Oyster Hemocyte Activation: Phagocytosis, Reduced Pyridine Nucleotides, and Reactive Oxygen Species Production. Environ Res Sect 78:72-78. doi: 10.1006/enrs.1999.4033

7. Baier-Anderson C, Anderson RS (2000b) Suppression of superoxide production by chlorothalonil in striped bass (Morone saxatilus) macrophages: the role of cellular sulfhydryls and oxidative stress. Aquat Toxicol 50:85-96

8. Barsiene J, Dedonyte V, Rybakovas A, et al (2006) Investigation of micronuclei and other nuclear abnormalities in peripheral blood and kidney of marine fish treated with crude oil. Aquat Toxicol 99104. doi: 10.1016/j.aquatox.2006.02.022

9. Brito LVR De, Coutinho R, Cavalcanti EHS, Benchimol M (2014) The influence of macrofouling on the corrosion behaviour of API 5L X65 carbon steel. Biofouling J Bioadhesion Biofilm Res 37-41. doi: 10.1080/08927010701258966

10. Caux PY, Kent RA, Fan GT, Stephenson GL (2015) Environmental fate and effects of chlorothalonil: A Canadian perspective. Crit Rev Environ Sci Technol 37-41. doi: 10.1080/10643389609388486

11. Cestari MM, Lemos PMM, Alberto C, et al (2004) Genetic damage induced by trophic doses of lead in the neotropical fish Hoplias malabaricus (Characiformes Erythrinidae) as revealed by the comet 
assay and chromosomal aberrations. Genet Mol Biol 274:270-274. doi.org/10.1590/S141547572004000200023

12. Da Silva Barreto J, De Melo Tarouco F, Da Rosa CE (2020) Chlorothalonil causes redox state change leading to oxidative stress generation in Danio rerio. Aquat Toxicol 225:105527. doi:

10.1016/j.aquatox.2020.105527

13. Da Silva Barreto J, Tarouco FM, De Godoi FGA, et al (2017) Induction of oxidative stress by chlorothalonil in the estuarine polychaete Laeonereis acuta. Aquat Toxicol 196:1-8. doi: 10.1016/j.aquatox.2017.12.004

14. Davies PE (1987) Disappearance rates of chlorothalonil in the aquatic environment. Bull Environ Contam Toxicol 4:405-410. doi: https://doi.org/10.1007/BF01689098

15. Davies PE (1988) Disappearance Rates of Chlorothalonil (TCIN) in the Aquatic Environment. Bull Environ Contam Toxicol 40:405-409. doi: https://doi.org/10.1007/BF01689098

16. Davies PE (1985) The toxicology and metabolism of chlorothalonil in fish. II. Gluthatione conjugates and protein biding. Aquat Toxicol 7:265-275. doi: https://doi.org/10.1016/0166-445X(85)90044-X

17. Gagné F (2014) Biochemical Ecotoxicology: principles and methods. In: Oxidative Stress. pp 103115

18. Gallo A, Tosti E (2015) Reprotoxicity of the Antifoulant Chlorothalonil in Ascidians: An Ecological Risk Assessment. PLoS One 1-14. doi: 10.1371/journal.pone.0123074

19. Garayzar ABS, Bahamonde PA, Martyniuk CJ, et al (2016) Hepatic gene expression pro filing in zebra fish (Danio rerio) exposed to the fungicide chlorothalonil. Comp Biochem Physiol Part D 19:102-111. doi: 10.1016/j.cbd.2016.04.004

20. García-Medina S, Galar-martínez M, Gómez-Oliván LM, et al (2017) Relationship between genotoxicity and oxidative stress induced by mercury on common carp (Cyprinus carpio) tissues. Aquat Toxicol 192:207-215. doi: 10.1016/j.aquatox.2017.09.019

21. Guerreiro A, Abreu F, Fillmann G, Sandrini J (2020) Effects of chlorothalonil on the antioxidant defense system of mussels Perna perna. Ecotoxicol Environ Saf 190:110119. doi: 10.1016/j.ecoenv.2019.110119

22. Guerreiro A da S, Rola RC, Rovani MT, et al (2017) Antifouling biocides: Impairment of bivalve immune system by chlorothalonil. Aquat Toxicol 189:194-199. doi: 10.1016/j.aquatox.2017.06.012

23. Hooftman R., Raat W. (1982) Induction of nuclear anomalies (micronuclei) in the peripheral blood erythrocytes of the eastern mudminnow Umbra pygmaea by ethyl methanesulphonate. Mutat Res 104:147-152. doi: 10.1016/0165-7992(82)90136-1

24. Kehrig HA, Costa M, Moreira I, Malm O (2002) Total and methylmercury in a Brazilian estuary, Rio de Janeiro. Mar Pollut Bull 44:1018-1023. doi https://doi.org/10.1016/S0025-326X(02)00140-6

25. Kiefer K, Bader T, Minas N, et al (2020) Chlorothalonil transformation products in drinking water resources: Widespread and challenging to abate. Water Res. doi: 10.1016/j.watres.2020.116066 
26. Kinkel MD, Eames SC, Philipson LH, Prince VE (2010) Intraperitoneal Injection into Adult Zebrafish. J Vis Exp 42:3-6. doi: 10.3791/2126

27. Lee $\mathrm{S}$, Chung J, Won $\mathrm{H}$, et al (2011) Analysis of antifouling agents after regulation of tributyltin compounds in Korea. J Hazard Mater 185:1318-1325. doi: 10.1016/j.jhazmat.2010.10.048

28. Lindberg HK, Wang $X$, Järventaus $H$, et al (2007) Origin of nuclear buds and micronuclei in normal and folate-deprived human lymphocytes. Mutat Res - Fundam Mol Mech Mutagen 617:33-45. doi: 10.1016/j.mrfmmm.2006.12.002

29. Long JW, Siegel MR (1975) Mechanism of action and fate of the fungicide chlorothalonil $(2,4,5,6-$ tetrachloroisophthalonitrile) in biological systems. 2. In vitro reactions. Chem Biol Interact 10:383394. doi: 10.1016/0009-2797(75)90069-1

30. Lopes F, Varela Junior A, Corcini C, et al (2019) Impacts of the biocide chlorothalonil on biomarkers of oxidative stress, genotoxicity, and sperm quality in guppy Poecilia vivipara. Ecotoxicol Environ Saf 188: doi: 10.1016/j.ecoenv.2019.109847

31. Marcovecchio JE (2004) The use of Micropogonias furnieri and Mugil liza as bioindicators of heavy metals pollution in La Plata river estuary, Argentina. Sci Total Environ 323:219-226. doi: 10.1016/j.scitotenv.2003.09.029

32. Mcmahon TA, Halstead NT, Johnson S, et al (2011) The Fungicide Chlorothalonil Is Nonlinearly Associated with Corticosterone Levels, Immunity, and Mortality in Amphibians. Environ Health Perspect 1098-1104. doi: 10.1289/ehp.1002956

33. Pompella A, Visvikis A, Paolicchi A, et al (2003) The changing faces of glutathione, a cellular protagonist. Biochem Pharmacol 66:1499-1503. doi: 10.1016/S0006-2952(03)00504-5

34. Sakkas VA, Konstantinou IK, Lambropoulou DA, Albanis TA (2002) Survey for the occurrence of antifouling paint booster biocides in the aquatic environment of Greece. Environ Sci Pollut Res 9:327-332. doi: $10.1007 / B F 02987576$

35. Segner H, Baumann L (2015) What constitutes a model organism in ecotoxicology? Integr Environ Assess Manag 12:199-200. doi: 10.1002/ieam.1734

36. Seriani R, Ranzani-paiva MJT, Silva-souza ÂT, Napoleão SR (2011) Hematology, micronuclei and nuclear abnormalities in fishes from São Francisco river, Minas Gerais state, Brazil. Acta Sci Biol Sci 33:107-112. doi: 10.4025/actascibiolsci.v33i1.7117

37. Shelley LK, Balfry SK, Ross PS, Kennedy CJ (2009) Immunotoxicological effects of a sub-chronic exposure to selected current-use pesticides in rainbow trout (Oncorhynchus mykiss). Aquat Toxicol 92:95-103. doi: 10.1016/j.aquatox.2009.01.005

38. Singh NP, McCoy MT, Tice RR, Schneider LE (1988) Technique for Quantitation Damage in Individual of Low Levels of DNA Cells'. Exp Cell Res 175:184-191

39. Speit G, Hartmann A (1995) The contribution of excision repair to the DNA effects seen in the alkaline single cell gel test (comet assay). 10:555-559

40. Suzuki T, Nojiri $\mathrm{H}$, Isono $\mathrm{H}$, Ochi $\mathrm{T}$ (2004) Oxidative damages in isolated rat hepatocytes treated with the organochlorine fungicides captan, dichlofluanid and chlorothalonil. Toxicology 204:97-107. doi: 
10.1016/j.tox.2004.06.025

41. Thomas K V., Brooks S (2010) The environmental fate and effects of antifouling paint biocides. Biofouling 26:73-88. doi: 10.1080/08927010903216564

42. Tice RR, Agurell E, Anderson D, et al (2000) Single Cell Gel / Comet Assay: Guidelines for In Vitro and In Vivo Genetic Toxicology Testing. Environ Mol Mutagen 221:206-221. doi. 10.1002/(sici)10982280(2000)35:3<206::aid-em8>3.0.co;2-j

43. Tillman RW, Siegel MR, Long JW (1973) Mechanism of Action and Fate of the Fungicide (2,4,5,6Tetrachloroisophthalonitrile) in Biological Systems 1. Reactions with Cells and Subcellular Components of Saccharomyces pastorianus. Pestic Biochem Physiol 3:160-167

44. Tortelli V, Colares EP, Robaldo RB, et al (2006) Importance of cholinesterase kinetic parameters in environmental monitoring using estuarine fish. Chemosphere 65:560-566. doi:

10.1016/j.chemosphere.2006.02.047

45. U.S. Environmental Protection Agency, 1999. Reregistration Eligibility Decision (RED) Chlorothalonil (EPA 738-R-99-004)

46. Juras, AA. (1984) Estudo sobre reprodução, regime alimentar e crescimento de Micropogonias furnieri (Desmarest, 1823) (Teleostei, Sciaenidae), capturada no litoral da Ilha de São Luis do Maranhão - Brasil. Tese. Universidade de São Paulo - USP.

47. Voulvoulis N, Scrimshaw MD, Lester JN (2000) Occurrence of four biocides utilized in antifouling paints, as alternatives to organotin compounds, in waters and sediments of a commercial estuary in the UK. Mar Pollut Bull 40:938-946. doi: 10.1016/S0025-326X(00)00034-5

48. Wu X, Cheng L, Cao Z, Yu Y (2012) Accumulation of chlorothalonil successively applied to soil and its effect on microbial activity in soil. Ecotoxicol Environ Saf 81:65-69. doi:

10.1016/j.ecoenv.2012.04.017

49. Yebra DM, Kiil S, Dam-Johansen K (2004) Antifouling technology - past, present and future steps towards efficient and environmentally friendly antifouling coatings. Prog Org Coatings 50:75-104. doi: 10.1016/j.porgcoat.2003.06.001

50. Zhang Q, Ji C, Yan L, et al (2016) The identification of the metabolites of chlorothalonil in zebra fish (Danio rerio) and their embryotoxicity and endocrine effects at environmentally relevant levels. Environ Pollut 218:8-15. doi: 10.1016/j.envpol.2016.08.026

\section{Figures}


A

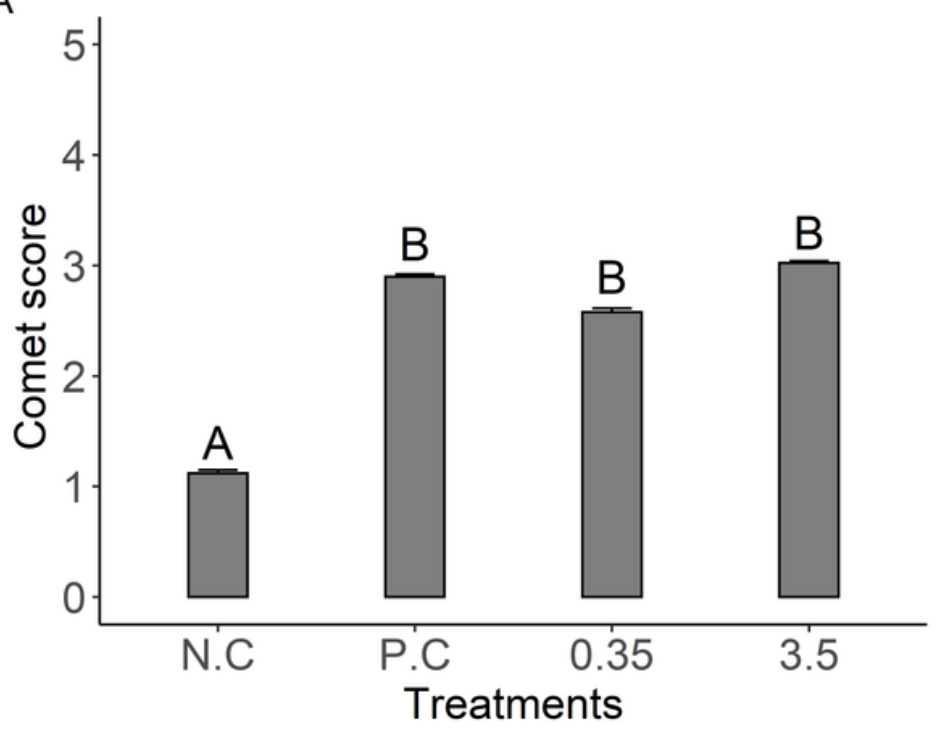

B

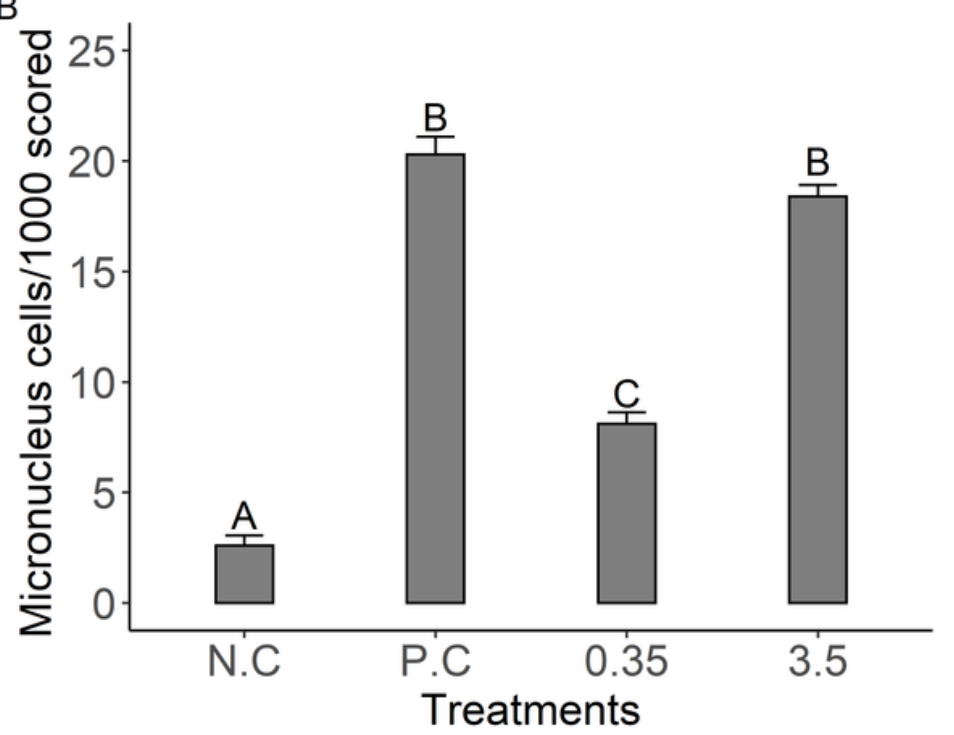

Figure 1

Mean (and standard error of the mean) damage scores (comet assay) (A) and frequency of micronuclei (B) for each treatment of M. furnieri exposed to chlorothalonil (0.35 $\mu \mathrm{g} \mathrm{g}-1$ and $3.5 \mu \mathrm{g} \mathrm{g-1)}$ compared to the negative (NC: saline solution and DMSO) and positive controls (PC: cyclophosphamide 50 $\mu \mathrm{g}$ g-1). Different letters above bars indicate statistically significant differences among treatments (Kruskal Walis - Dunnet, $p<0.05$ ). 

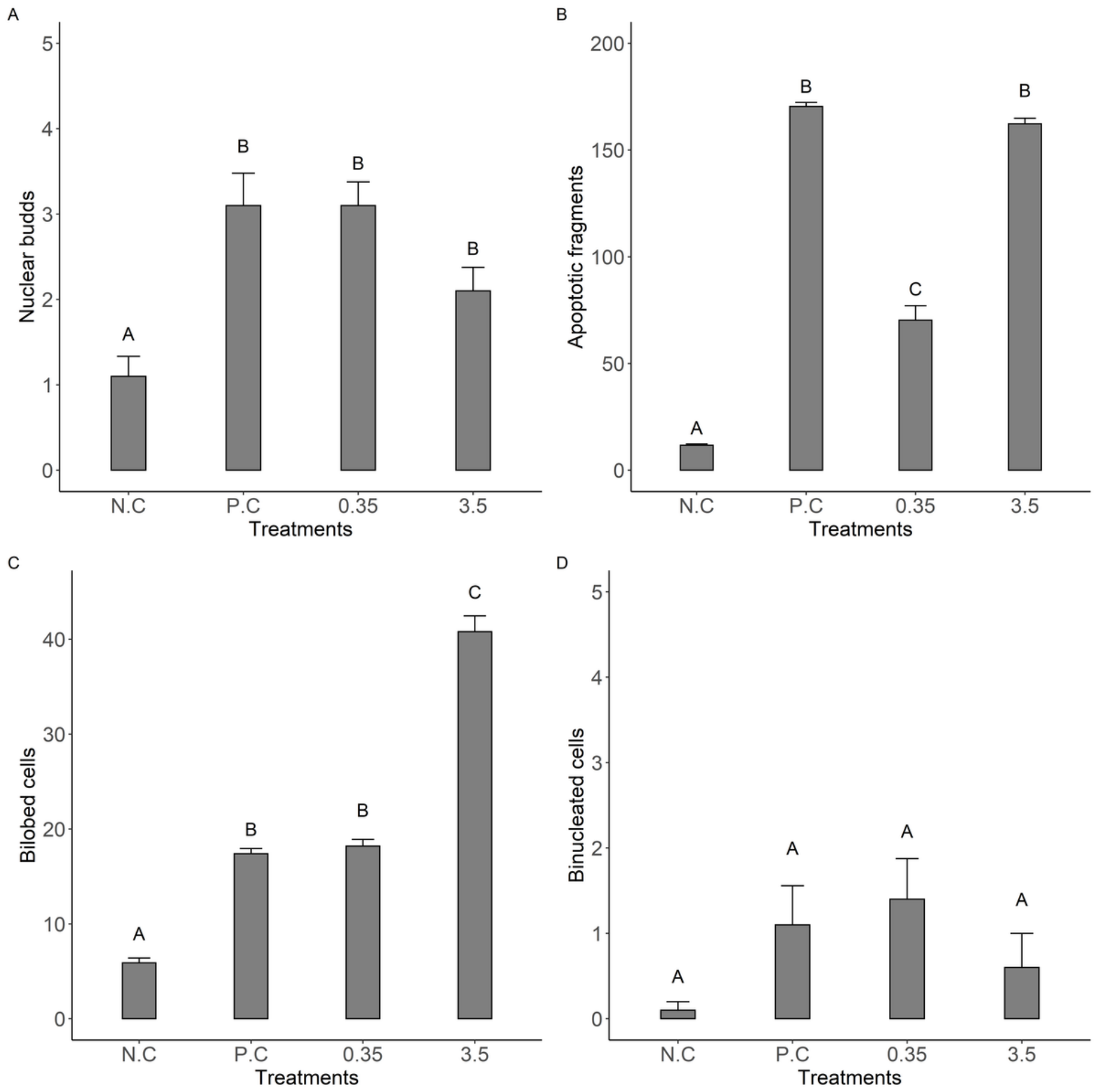

\section{Figure 2}

Mean (and standard error of the mean) frequencies of nuclear abnormalities (A: nuclear buds; $B$ : apoptotic fragments; C: bilobed cells; D: binucleated cells) for the different treatments of $M$. furnieri exposed to chlorothalonil $(0.35 \mu \mathrm{g} \mathrm{g}-1$ and $3.5 \mu \mathrm{g} \mathrm{g}-1)$ in comparison to the negative (NC: saline solution and DMSO) and positive controls (PC: cyclophosphamide $50 \mu \mathrm{g} \mathrm{g}-1$ ). Different letters above bars indicate statistically significant differences among treatments (Kruskal Walis - Dunnet, $p<0.05$ ). 